\title{
Taxation and Balance of Payments in Nigeria (1970 - 2008)
}

\author{
Johnson A. Atan, Ph.D \\ Department of Economics University of Uyo, Uyo.
}

\begin{abstract}
This paper examines the implication of using taxation to manage the Nigerian Economy and the influence of such measure on macroeconomic aggregates, especially balance of payments over the period 1970 - 2008. The analysis was carried out using both descriptive and inferential statistical techniques. The Ordinary Least Square (OLS) method was used for the estimations. Our findings indicate that the historical trends in balance of payments showed no significant response to tax policy. A positive relationship between tax policy and balance of payments was obtained, which is in line with the theory, but with insignificant coefficient. Further, we found that taxation was not effective in tackling balance of payments problems in the economy during the period of study largely because of inconsistency in the use of tax measures. Among other recommendations, the paper submits that Nigeria should apply tax measures much more carefully than was observed over the period studied.
\end{abstract}

\section{Introduction}

Tax Policy plays an important role in economic management of nations. Both the more developed and less developed countries (MDCs and LDCs) employ tax policy to improve their fiscal and economic performance. In the short run policy-makers formulate tax policies to complement expenditure restraint aimed to contain macroeconomic imbalances (Bovenberg, 1985). Governments can regulate the economy (that is, encouraged or discourage particular forms of social behaviour) by manipulating the incidence of taxation. Tax incentives, for example, tax reduction, tax holidays, are given usually to promote investment and boost output. For instance, tax reduction in the agricultural sector is believed to prompt farmers and other operators in the sector towards greater productivity. The reverse also applies: a heavy tax on the luxury goods will reduce public demand and shift productive resources to other areas (Smatrakalev, 2005).

Taxes are at the foundation of public finances, they are the principal means by which governments fund their expenditures. A properly designed tax policy implies readier tax payer acceptance of that expenditure burden. It should promote the maintenance of a high and sustainable level of output by minimizing both distortions to market-set prices and disincentives to work, saving and investment. But optimal tax policy goes beyond mere efficiency and funding considerations to encompass inevitable normative judgments about the amount of redistribution (Smartrakalev, 2005). By this, Smartrakalev (ibid) tries to explain that taxation and tax policy can be used to control and direct economic management. The regulative role of taxation is one of the most pronounced roles from the fiscalists. The optimal tax policy turns out to affect the economy countercyclically via procyclical taxes, that is, "cooling down" the economy with higher taxes when it is "overheating" due to a positive productivity shock (Ljungqvist \& Uhlig 2000). The explanation is that agents would otherwise end up consuming too much in boom times since they are not taking into account the "addiction effect" of a higher consumption level. In recessions, the effect goes the other way round and taxes should be lowered to "stimulate" the economy by bolstering consumption.

At one level, that taxation influences economic behaviour has become a basic tenet for economic policymakers. For example, taxation is assumed to influence multinational firms' financial decisions about repatriation of profits. The World Bank relates economic performance in developing countries to the level of taxation and finds that countries with lower marginal tax rates have higher Level of spending, inflation rate and balance of payments problems. The reverse is the case with countries having higher marginal tax rates.

In Nigeria, economic indicators have shown that in spite of various tax policies, the expected goals are yet to be achieved. This is evidenced by high rates of inflation and unemployment, decreasing capacity utilization leading to slow growth rate and persistence balance of payments problems. Practically, the Nigerian economy, for the past decades, has been experiencing problems of instability of major economic aggregates unemployment, price level (inflation), rate of growth of the economy and balance of payments. For instance, in the successive National Development Plans and various annual budgets, single digit inflation rate and a favourable balance of payments situation were targeted. But the available data reveals that the target was hardly ever achieved.

Nigerian Governments have over the years, and on annual bases, set out her taxing and expenditure profile through budgets depending on the objectives it wants to achieve. Such actions which form the basis of tax policy (fiscal policy) are formulated to either "gear up" or stabilize the economy, i.e. steer the economy in 
the desired direction (Ukpong \& Akpakpan 1998). Various tax policies as explained by the adoption of a specific budget in Nigeria have witnessed a persistent balance of payments problem rather than yielding corresponding favourable and expected balance of payments situation in the economy. The choice of some types of tax by the government has placed some sectors of the economy on a higher priority than others. Several questions have also been raised as to how successive government tax policies have achieved the goals and objectives they intended, and the extent to which they have responded to the working of the economy.

This paper seeks to investigate the extent to which successive governments used taxation in solving the balance of payments problems in the Nigerian economy during period 1970 to 2008 . The paper is arranged in five sections with the foregoing introduction as the first. The second section features the review of theoretical and empirical issues in taxation and balance of payments. The third section specifies the model while the fourth section presents and discusses the regression results. The last section concludes with some recommendations.

\section{Theoretical Issues}

Adam Smith and other classical economists, in their canon of taxation, had documented what should constitute a good tax. A good tax, ipso facto, should possess the following attributes:

a) The distribution of the tax burden should be equitable i.e., everybody should pay his/her fair share;

b) Taxes should be chosen so as to minimize interference with economic decisions in otherwise efficient markets. Such interference imposes "excess burden" which should be minimized;

c) Where tax policy is used to achieve other objectives such as to grant investment incentives, this should be done so as to minimize interference with the equity of the system;

d) Tax structure should facilitate the use of fiscal policy for stabilization and growth objectives;

e) The tax system should permit fair and non arbitrary administration and it should be understandable to the tax payer;

f) Administration and compliance cost should be as low as is compatible with the other objectives (Musgrave and Musgrave 1989:216).

The various objectives are not necessarily in agreement and where they conflict, tradeoffs between them are needed. Thus, equity may require administrative complexity and may interfere with neutrality, efficient design of tax policy may interfere with equity, and so forth.

Adawo (2001), in support of the classical attributes of taxes, maintained that a tax system should be equitable i.e., each tax payer should contribute his/her 'fair share' to the cost of government. But the term 'fair share' is not easy to define. In particular, two strands of thought may be distinguished. One approach rests on the benefits principle. According to this theory, an equitable tax system is one under which each tax payer contributes in line with benefits, which he/she receives from public services. The benefit criterion, therefore, is not one of tax policy only but of tax-expenditure policy. Here economics of the public sector is viewed as involving a simultaneous solution to both its revenue and its expenditure aspects.

The other strand rests on the ability-to-pay principle. Here the tax problem is viewed by itself independent of expenditure determination. A given revenue is needed and each tax payer is asked to contribute in line with his or her ability to pay. This approach leaves the expenditure side of the public sector dangling and is thus less satisfactory from the economists' point of view (Musgrave and Musgrave, 1989:219). But actual tax policy is largely determined independent of the expenditure and an equity rule is needed to provide guidance. The ability to pay principle is widely accepted as a guide.

However, neither approach is easy to interpret or implement. For the benefit principle to be applied, expenditure benefits for particular tax payers must be known. For ability-to-pay approach to be applicable, it is necessary to know how this ability is to be measured. These are difficulties and neither approach wins on a practical ground. Moreover, neither approach can be said to deal with the entire function of tax policy.

The benefit approach will allocate that part of the tax bill which defrays the cost of public services, but it cannot handle taxes needed to finance transfer payments and serve re-distributional objectives. For the benefit of taxation to be equitable, it must be assumed that a 'proper' state of distribution exists. In practice, there is no separation between the taxes used to finance public services and the taxes used to redistribute income. The ability-to-pay approach meets the redistribution problem but leaves the provision for public services undetermined.

But as Musgrave and Musgrave (1989:219), have argued, both principles have important, if limited, application in designing an equitable tax structure, one which is acceptable to most people and preferable to alternative arrangement.

In a modern economy, taxes are not just designed to raise revenue for government, it is in addition, an instrument of economic management, an instrument for controlling the economy. The control consists in regulating spending to ensure that the right levels are achieved; that is, levels that enable the system to avoid recession and balance of payments problem (Akpakpan, 1999). 
To be able to manage the economy in such a way that neither a recession nor balance of payments problem occurs, the government must assess the economic situation. It must determine accurately whether the economy needs to be stimulated, and to what extent; whether it needs to be restrained, and to what extent; or whether things are all right. The assessment of the economy in this wise, determines the kind of taxes to be introduced, which will in turn determine, to a large extent, the state of the economy. Where the government's assessment suggests that the economy needs to be stimulated, a lower tax rate is usually introduced to boost export spending where it suggests that it needs to be restrained, a higher tax rate is usually introduced to reduce import spending. With taxes, government can control the working of the economy in terms of maintaining a favourable balance of payments.

\subsection{Tax Policy and Balance-of-Payments}

The approach towards solving the balance-of-payments problem depends on its cause. If the problem is caused by a deficit on the current account, which shows that the country has imported more goods and services than it has exported, the country will have to strive to increase its exports and reduce its imports (Akpakpan 1999). The specific tax policies which could keep a country in pursuing this objective include the following:

(a) Import restriction through tariffs. Tariff may be specific and/or Ad valorem. A specific tariff is an import duty that assigns a fixed monetary (Naira) tax per physical unit of the good imported. Thus, a specific duty might be $\$ 75$ per ton imported or 5 kobo per Naira. The total import tax bill is levied in accordance with the number of units coming into the importing country and not according to the price or value of the imports. The ad valorem tariff is levied as a constant percentage of the monetary value of 1 unit of the imported good. Thus, if the ad valorem tariff rate is $10 \%$, an imported good with world price $\$ 10$ will have a $\$ 1$ tax added as the import duty (Appleyard and Field 2001).

Thus, an increase in tariff will lead to a decline in imports.

(b) Another policy measure is to stimulate export production in particular in order to increase the earnings from exports. To be successful in this, those engaged in production for export should be given export incentives in the form of tax incentives in order to strive to produce high quality products. A reduction in export tax will encourage export leading to an excess of exports over imports (a favourable balance of payments). Writing in these mould are Ekpo (2005), McConnell and Brue (1999), Cobham (1981), Hyman (2005), Gordon and li (2009), Udabah (2002) among others.

Theoretical underpinnings have been provided for taxation as an instrument of fiscal policy in solving balance of payments problems, but empirical investigation into the matter have been rather scanty. Anyanwu (1997)'s "Effects of taxes on Nigeria's Balance of Payments" is a work worthy of review. The work set out to investigate the impact of taxes on balance of payments in Nigeria paying attention to tax policy adopted between 1981 and 1996. Using the 1981-1993 data and the log-linear regression analysis, he observed that the hypothesis that taxes have no influence on balance of payments was not accepted for the country's tax system as a whole. He concluded that, though the coefficient of tax policy in his balance of payments model was not significant, his result shows that taxes significantly influence Nigeria's balance of payment as the former varies negatively with the later.

Uwatt (1999) evaluated revenue productivity in the Nigerian Federal System. His work unlike previous works cited considered in addition to tax revenue, non-tax revenue. His estimations drew from the recent developments in co-integration analysis and the error correction mechanism. His findings were that over the years under consideration, major revenue sources have increased but their productivity not very impressive. He concludes by recommending appropriate tax reforms and improvement in tax administration in Nigeria.

Kusi (1998) did a similar work for the Ghanaian economy. In his work "Tax Reform and Revenue Productivity in Ghana", he observed that tax reform had been used as an instrument for raising the revenue productivity of the Ghanaian tax system. This he did using the traditional methods of estimation of tax elasticities. These are the historical time-series tax data (HTSTD) adjusted to discretionary tax measures (DTULS) and the unadjusted HTSTD with time trends as proxies for DTWS. His analysis covered the period 1970-1993 where pre-tax reform period covered 1970-1982 and tax reform period covered 1983-1993.

His findings were that estimates of buoyancies and income elasticities of individual taxes and the overall tax system, based on empirical evidence, show that the tax reform process contributed greatly to the growth of revenue enhancement options, including the introduction of VAT to replace the existing sales tax then, revaluing properties to broaden the base of property tax, among others.

Chipeta (1998)'s "Tax reform and tax yield in Malawi" is another work worthy of review. The work set out to evaluate tax reforms in Malawi paying particular attention to tax reforms undertaken in the 1980s and early 1990s which were far reaching and more numerous than those of the 1970s. Using the 1980-1993 data and the dummy variable technique developed by Singer (1968), he observed that the hypothesis that tax yield was not buoyant was accepted for the tax system as a whole. This was also applicable for minimum tax, minimum tax remittances, graduated tax, assessed tax, fringe benefit tax, excise and import duties, licenses and taxes on 
property. Also, that the income elasticity of the tax system was lower than unity. This appeared to be due to the generally low base to income elasticities of surtax, import duties, PAYE and excise duties. This implies that tax bases had grown less rapidly than GDP - concluding that base to income elasticities can be increased by improving the growth of domestic manufacturing output, expanding formal imports of dutiable goods and by improving the growth of wages.

Ariyo (1997) assessed the buoyancy of the Nigerian tax system as a whole and of various tax sources. This he did by introducing administrative lags (proxied by a one-year lag explanatory variable), intercept and slope dummy variables into the model (traditional tax buoyancy equation). The dummy variables were introduced to practically assess the potential implications for tax yield of the oil-boom and the Structural Adjustment Programme (SAP). His work revealed that there are wide variations in the level of productivity by tax source with the oil boom encouraging some laxity in the management of non-oil revenue sources. He adds that the level of efficiency in tax administration seems to vary inversely with the overall state of the economy. In conclusion the work suggests that leakages should be minimized in terms of tax evasion and diversion of tax proceeds.

Kumhof (2004), presented a model of fiscal and monetary policies that evaluates the trade off between higher distortionary labour taxation and higher inflation in the resolution of fiscal crises. In a cross-country analysis, he used data for the period 1997 to 2000, to permit a generalization of existing fiscal theories of the price level by making price level determination the outcome of an explicit government optimization problem over a tax distortion and an inflation distortion. Higher taxes have a distortionary effect on labour supply but a beneficial effect by lowering inflation and supporting a higher public debt stock that in turn supports intermediation and the capital stock. He concluded that a large contribution of inflation to the resolution of fiscal crises is only optimal when the fiscal shock is transitory, while a long-lived shock is optimally financed mostly through taxes.

A common observation in some of the studies cited above is the acknowledgement of the cross-country regression of tax policy and economic management as we had earlier said in this study. Apart from Anyanwu (1997), many of them investigated the tax revenue position of the Nigerian economy and suggested ways of improving on the revenue programmes. Some scholars examined the General Equilibrium analysis of sectoral effects of tax policy in Nigeria. It is also observed that all of them actually neglected that aspect which relates to the use of tax policy in steering the economy to the desired direction. That is, how tax policy was used to influence the working of the economy in terms of promoting a favourable balance of payments position, among others. Hence our study is necessary as it seeks to examine the extent to which tax policy has been used in the management of a real-world economy, the Nigerian Economy.

Table 1 (at appendix) presents the trend in some macroeconomic aggregates in the Nigerian economy. A careful view of the table witnessed surpluses and deficits in the balance of payments in most of the periods. The deficits arose out of the huge import expenditure which the country had to incur in the face of low food production and lack of adequate supply of industrial products and materials. The Nigerian economy is one that consumes what it cannot produce and produces what it cannot consume. The enormous revenue from oil encouraged such a heavy expenditure on import. Further, it is observed that, there were deficits in the balance of payments during the years 1970, 1971, 1973, 1976, 1977, 1978, 1993, 1994, 1995, 1998 and 2002 while surpluses were recorded in other years. There was an increase in average tax rate (ATR) from approximately 0.12 in 1970 to 0.2 in 1971 and then to 0.22 in 1972. In 1976, ATR was 0.16 when the BOPs recorded a deficit of 258.4. This rose to 1157.4 in 1978 when the ATR also rose to 0.19. It is also observed that in some periods (1979 - 1989), an increase or decrease in ATR lead to a surplus BOPs. For some periods, a decrease in ATR lead to a reduction in the balance of payments position (surplus or deficits). In some periods, an increase in ATR out rightly leads to an increase in BOPs (surplus or deficit). For instance, between 1990 to 2006, ATR steadily moves from 0.144 in 1990 to 4.50 in 2006 when the BOP recorded a surplus balance of $79810.1 \mathrm{~m}$ in 1990, and the balance reduced to $51969.8 \mathrm{~m}$ in 1991, but increased to $93,680.5$ in 1992 and thereafter recorded a deficit balance of $34414.7 \mathrm{~m}, 52304.3 \mathrm{~m}$ and $188084.8 \mathrm{~m}$ in 1993, 1994 and 1995 respectively.

\section{Model Specification}

Apart from the time series data on the individual taxes, total tax revenue and GDP, estimation of tax effects on target variables requires a specification of the potential proxy for tax policy (taxation). For this paper, we will use average tax rate (that is, total tax revenue over GDP) as a measure of tax policy. This is in line with the literature ( see Angelopoulos, Economides and Kammas ,2007). Following Ekpo, Ndebbio, Akpakpan and Nyong (2004), our model is specified as:

$$
\begin{gathered}
\mathrm{BOP}=\mathrm{f}_{0}+\mathrm{f}_{1} \mathrm{GDP}+\mathrm{f}_{2} \mathrm{NFO}+\mathrm{f}_{3} \mathrm{ED}+\mathrm{f}_{4} \mathrm{EXCH}+\mathrm{f}_{5} \mathrm{MGS}+\mathrm{f}_{6} \mathrm{ATR}+\mathrm{f}_{7} \mathrm{OPN}+\mathrm{U}_{5} \\
\ldots .(1) \\
\mathrm{f}_{1}, \mathrm{f}_{2}, \mathrm{f}_{3}, \mathrm{f}_{4}, \mathrm{f}_{6} \text { and } \mathrm{f}_{7}>0 ; \mathrm{f}_{4}<0
\end{gathered}
$$


Where $\mathrm{BOP}=$ Balance on Current Account, $\mathrm{ED}=$ External Debt, NFO = Net Fiscal Operation, GDP $=$ Real Gross Domestic Product, $\mathrm{ATR}_{\mathrm{t}}=$ Average Tax Rate measured as the ratio of tax revenue to GDP, $\mathrm{OPN}=$ Openness of the economy measured as the sum of export and import as a ratio of GDP, $\mathrm{EXCH}_{\mathrm{t}}=$ Current exchange rate, $\mathrm{MGS}_{\mathrm{t}}=$ Money Supply Growth rate

\subsection{Unit Root Test}

\section{Results and Discussion}

The regression results of the unit root test for all the variables are presented in Table 2 (at appendix). Based on the Augmented Dickey-Fuller (ADF) test, the results show that four variables -average tax rate (ATR), MSG (money supply growth rate), openness of the economy (OPN), and the Net Foreign Operation (NFO) are stationary at levels, while the remaining four variables - exchange rate $(\mathrm{EXCH})$, Balance of Payments (BOP), Gross Domestic Product (GDP) and external debt (ED) - are stationary at first difference. At the first difference, therefore, all the variables are stationary. This is because the ADF statistic for all the variables are all greater (in absolute terms) than their respective critical values at $5 \%$ level of significance. This implies a rejection of null hypothesis of non-stationarity at $5 \%$ level of significance. The obvious conclusion from these results is that the OLS regression may not produce "spurious" results since all the variables are difference stationary. The next stage of our analysis is to determine if the variables have long-run relationships through the process of cointegration.

\subsection{Cointegration Test}

Time series data which are individually non-stationary at levels can be stationary when a linear combination of them is considered. When this is the situation, then it implies that there exist a linear long-run relationship among the variables. As shown by the unit root test results, four variables were non-stationary at levels and this suggests that cointegration tests be carried out to confirm the existence and otherwise of long-run linear relationship among the variables of the model. The cointegration results based on Johansen maximum likelihood are presented in Tables $3 \mathrm{a}$ and $3 \mathrm{~b}$ (at Appendix). Our result shows that there are at least three cointegrating equations (going by the trace statistic) or at least two cointegrating equations (going by the maxeigen value test statistic). Overall, this implies that our regression results depict a long-run relationship among the variables although there might be some deviations in the short run.

\subsection{Regression Results}

The estimation results for our model are presented in Table 4 (at appendix). The equation represents formulations of the hypothesis that taxation has no influence on the balance of payments position in the Nigerian economy.

Taken together, the equations represent a "good fit" with more than $97 \%$ of the systematic variation in the balance of payments being explained by the model on the average. The equation also passed the F-test of significance at $1 \%$ level. An examination of this equation shows that it performs better, posting the higher adjusted $\mathrm{R}^{2}$ of $97 \%$ and F-statistic of 189.85. Moreover, the Durbin-Waston statistic test showed that the equation was free from auto correlation problem. An examination of the major arguments in the balance of payments reveal that while some conform to economic theory, others do not. Beginning with our variable of interest, average tax rate (ATR), it is observed that the coefficient of this variable has a positive sign in the equation. This is in line with a priori expectation. Since it suggests that the relationship between taxation and balance of payments position in Nigeria is positive. The t-test confirms that ATR coefficient in this equation is not statistically significant even at $10 \%$. The problem of multicolinearity is encountered. The correlation analysis reveals that some variables - openness $(\mathrm{OPN})$, exchange rate $(\mathrm{EXCH})$, net foreign operation $(\mathrm{NFO})$, MSG, external debt (ED) and GDP are strongly correlated.

Further, we adopted the method of first difference form to reduce the severity of multicollinearity and the results are presented in Table 5(at appendix). The results showed that $\mathrm{R}^{2}$ is $82 \%$, while adjusted $\breve{\mathrm{R}}^{2}$ is $78 \%$. These results represent a "fairly good fit" with about $82 \%$ of the systematic variation in the BOP being explained by the model on average. The F-statistic test is significant at even less than $1 \%$ level of significance. The Durbin-Watson statistic test revealed that the transformed equation was free from auto correlation problem. But the coefficient of ATR (the variable of interest) is not only negative, contrary to the a priori expectation, but also insignificant even at $10 \%$ level of significant. Further, it is also observed that the coefficient of external debt and that of MSG is negative as was earlier observed in Table 4. Same is observed in the case of gross domestic product (GDP), net foreign operation (NFO), openness (OPN) and exchange rate (EXCH), with their coefficients having a positive sign but insignificant in terms of t-test, exception of NFO. The F-statistic (the test for overall significance of the coefficients) in all models - linear and first difference form - are quite satisfactory. Hence, the result of the linear form and that of the first difference form are almost the same. 


\section{Findings and Recommendations}

From the empirical analysis, we observed that:

(i) Even though theoretical reasoning holds that tax policy is a major instrument in economic management in terms of solving the balance of payments problems, the historical trends in balance of payments in Nigeria showed no significant response to tax policy between the period 1970 to 2008 . Tax policy may not have been used for the purpose of solving the balance of payments problems in the economy as this variable showed insignificant response to changes in tax policy during the period.

(ii) The tax system in Nigeria appears to have performed poorly in terms of controlling the working of the economy. The trends in balance of payments have not moved in any direction with that of taxation between the periods under review. This variable has not responded significantly to changes in taxation during that period.

(iii) In the balance of payments equation the coefficient is not significant, even though the sign is in line with the a priori expectation. The F-statistics is significant even at less than $1 \%$ and about $98 \%$ of the systematic variation in the balance of payments is explained by the model on the average. This again, represents a good fit.

(iv) However, an overall evaluation of the tax system in Nigeria reveals a dismal performance of the tax policy in Nigeria. This could probably be attributed to the upsurge in oil prices, which led to periodical increase in revenue.

The implications are that taxes were not effective in improving the balance of payments situations in the economy during the period 1970 to 2008. Given the important roles taxes could play in the management of our economy, we proffered the following recommendations:

(i) There is a need for government and our tax authorities to adopt a sound tax policy framework and a more promising implementation strategy.

(ii) Taxes should be linked to economic conditions in the country.

(iii) The use of tax policy in economic management in Nigeria should be taken more seriously than what was done during the period studied.

(iv) However, a more effective policy might be to reform the tax system, realign expenditure to citizen demands. The application of benefits principle should be rigorously pursued.

(v) The government should set targets and actively pursue same. This could strengthen the assessment, collection and enforcement of taxes. This should help improve tax administration and the effective use of tax in the management of the economy.

\section{References}

[1]. Adawo, M. A. (2001). Tax Avoidance and Tax Evasion at the Local Level: Any End in Sight. In: A. H. Ekpo and O. J. Umoh, (Eds.) Revenue Generation and Tax Administration in Akwa Ibom State of Nigeria. Uyo: Foundation for Economic Research and Training (FERT) Publishers. Pp $13-22$.

[2]. Akpakpan, E. B. (1999). The Economy: Towards a New Type of Economics. Port Harcourt: Belport Publishers.

[3]. Angelopoulos, K. G. Economides and Kammas, P. (2006). "Tax - Spending Policies and Economic Growth: Theoretical Predictions and Evidence from the OECD”. European Journal of Political Economy 23: 885 - 902.

[4]. Anyanwu, J. C. (1997). Nigerian Public Finance. Nigeria: Joanee Educational Publishers.

[5]. Anyanwu, J. C. and H. E. Oaikhenan (1995). Modern Macroeconomics: Theory and Applications in Nigeria. Onitsha, Joanee Educational Publishers.

[6]. Appleyard, D. R. and A. J. Field (2001). International Economics. USA: McGraw-Hill/Irwin.

[7]. Ariyo, A. (1997). Productivity of the Nigerian Tax System: 1970-1990. An AERC Publication. Paper 67.

[8]. Bovenberg, A. L. (1985). Indirect Taxation in Developing Countries: A General Equilibrium Approach. Economics Letters (Amsterdam), 14: $333-373$.

[9]. Central Bank of Nigeria (CBN) Annual Report and Statement of Accounts. Various Issues.

[10]. Central Bank of Nigeria (CBN) Statistical Bulletin. Several Issues.

[11]. Chipeta C. (1998). Tax Reform and Tax Yield in Malawi. An AERC Publication. Paper 73.

[12]. Cobham D. (1981). On the Causation of Inflation: Some Comments in the Manchester School of Economics and Social Studies, 4: $348-354$.

[13]. Ekpo, A. H., J. U. Ndebbio, E. B. Akpakpan and E. O. Nyong (2004). Macroeconomic Model of the Nigerian Economy, Ibadan: Vintage Publishers.

[14]. Ekpo, A. H. (2005). Fiscal Theory and Policy: Selected Essays. Lagos: Somaprint Ltd.

[15]. Federal Office of Statistics, Annual Abstract of Statistics (various issues).

[16]. FRN Annual Budgets (various years).

[17]. Gordon, R. and W. Li (2009). Tax Structures in Developing Countries: Many Puzzles and a Possible Explanation. Journal of Public Economics, 93: $855-866$.

[18]. Hyman, D. N. (2005). Public Finance: A Contemporary Application of Theory to Policy. South-west, United States of America: Thomson Learning.

[19]. Kumhof, M. (2004). Fiscal Crisis Resolution: Taxation versus Inflation. Working Paper, MIT.

[20]. Kusi, N. K. (1998). Tax Reform and Revenue Productivity in Ghana. An AERC Research Paper.

[21]. Ljungqvist, L., and H. Uhlig (2000). Tax Policy and Aggregate Demand Management, under Catching Up with the Joneses. Journal of Political Economy, 107(2): $356-366$.

[22]. McConnell, C. R. and S. L. Brue (1999). Economics: Principles, Problems and Policies. U.S.A.: McGraw-Hill.

[23]. Musgrave, R. A. and P. B. Musgrave (1989). Public Finance in Theory and Practice. New Delhi: McGraw-Hill, 
[24]. Smatrakalev, G. (2005). Taxation and Tax Policy in the E-world, Journal of Economic Literature; 34(2): 1 - 13.

[25]. Udabah, S. I. (2002). An Introduction to Nigerian Public Finance. Enugu: Linco Press, Nig. Ltd.

[26]. Ukpong, I. I. And E. B. Akpakpan (1998). The Nigerian Fiscal System. Port Harcourt: Belpot Publishers.

[27]. Uwatt, U. B. (1999). Revenue Performance and Productivity in the Nigerian Federal System. Nigerian Journal of Economic and Social Studies. 41(2): $175-203$.

[28]. World Bank (2007). World Development Indicator, New York: Oxford University Press.

APPENDIX

Table 1: Trend Analysis of Major Economic Management Variables in Nigeria

\begin{tabular}{|c|c|c|c|c|c|c|}
\hline YEAR & $\begin{array}{c}\text { GDP } \\
\text { (\#'M) }\end{array}$ & $\begin{array}{c}\text { TR } \\
\text { (\#'M) }\end{array}$ & $\begin{array}{c}\mathrm{EXCH} \\
(\%)\end{array}$ & $\begin{array}{r}\text { ED } \\
\left(\#^{\prime} M\right)\end{array}$ & $\begin{array}{c}\text { BOP } \\
\text { ('M) }\end{array}$ & ATR \\
\hline 1970 & 4219.00 & 513.5 & 0.7143 & 178.5 & -50 & 0.121711 \\
\hline 1971 & 4715.50 & 941.6 & 0.6955 & 265.6 & -229.4 & 0.199682 \\
\hline 1972 & 4892.80 & 1102 & 0.6579 & 276.9 & -322.7 & 0.225229 \\
\hline 1973 & 5310.30 & 1366.2 & 0.6579 & 322.4 & 52.7 & 0.257274 \\
\hline 1974 & 15919.70 & 800.2 & 0.6299 & 349.9 & 4671.5 & 0.050265 \\
\hline 1975 & 27172.00 & 3730.1 & 0.6159 & 374.6 & 42.6 & 0.137277 \\
\hline 1976 & 29146.50 & 4729.8 & 0.6265 & 365.1 & -258.4 & 0.162277 \\
\hline 1977 & 31520.30 & 1622.5 & 0.6466 & 1252.1 & -647.5 & 0.051475 \\
\hline 1978 & 29212.40 & 5641.3 & 0.606 & 1611.5 & -1157.4 & 0.193113 \\
\hline 1979 & 29948.00 & 6883.1 & 0.5957 & 1866.8 & 9427.3 & 0.229835 \\
\hline 1980 & 31546.80 & 10957 & 0.5464 & 2331.2 & 13057.9 & 0.347325 \\
\hline 1981 & 205222.10 & 9054.6 & 0.61 & 8819.4 & 10070.3 & 0.044121 \\
\hline 1982 & 199685.30 & 7732.4 & 0.6729 & 10577.7 & 7980.9 & 0.038723 \\
\hline 1983 & 185598.10 & 6292.5 & 0.7241 & 14808.7 & 6752.3 & 0.033904 \\
\hline 1984 & 183563.00 & 7164.6 & 0.7649 & 17300.6 & 8234.3 & 0.039031 \\
\hline 1985 & 201036.30 & 9898.8 & 0.8938 & 41452.4 & 10738.9 & 0.049239 \\
\hline 1986 & 205971.40 & 7641.7 & 2.0206 & 100789.1 & 8006.6 & 0.037101 \\
\hline 1987 & 204806.50 & 17280 & 4.0179 & 133956.3 & 17138.2 & 0.084372 \\
\hline 1988 & 219875.60 & 14037.2 & 4.5367 & 240393.7 & 31586.1 & 0.063842 \\
\hline 1989 & 236729.60 & 18327.9 & 7.3916 & 298614.4 & 59112 & 0.077421 \\
\hline 1990 & 267550.00 & 38547.2 & 8.0378 & 328453.8 & 79810.1 & 0.144075 \\
\hline 1991 & 265379.10 & 53900.7 & 9.9095 & 544264.1 & 51969.8 & 0.203108 \\
\hline 1992 & 271365.50 & 72948.7 & 17.2984 & 633144.4 & 93680.5 & 0.268821 \\
\hline 1993 & 274833.30 & 84248.7 & 22.0511 & 648813 & -34414.7 & 0.306545 \\
\hline 1994 & 275450.60 & 80632.9 & 21.8861 & 716865.6 & -52304.3 & 0.292731 \\
\hline 1995 & 281407.40 & 122861.2 & 21.8861 & 617320 & -188085 & 0.436595 \\
\hline 1996 & 293745.40 & 184667 & 21.8861 & 595931.9 & 240180 & 0.628663 \\
\hline 1997 & 302022.50 & 121574.1 & 21.8861 & 633017 & 268899.4 & 0.402533 \\
\hline 1998 & 310890.10 & 301900 & 21.8861 & 2577374 & -331436 & 0.971083 \\
\hline 1999 & 312183.50 & 359900 & 92.6934 & 3097384 & 46336.2 & 1.152848 \\
\hline 2000 & 329178.70 & 769200 & 102.1052 & 3176291 & 713023.9 & 2.336725 \\
\hline 2001 & 356994.30 & 1016700 & 111.9433 & 3932885 & 108996 & 2.847945 \\
\hline 2002 & 433203.50 & 781600 & 120.9702 & 4478329 & -177037 & 1.804233 \\
\hline 2003 & 477533.00 & 1130200 & 129.3565 & 4890270 & 704560 & 2.366747 \\
\hline 2004 & 527576.00 & 1571500 & 133.5004 & 2695072 & 2056326 & 2.978718 \\
\hline 2005 & 561931.40 & 2456100 & 131.6619 & 451461.7 & 4046521 & 4.370818 \\
\hline 2006 & 595821.60 & 2682500 & 131.76 & 428058.7 & 3374806 & 4.502187 \\
\hline 2007 & 634251.10 & 271672 & 129.25 & 452076.3 & 2703754 & 0.428335 \\
\hline 2008 & 674889.00 & 273800 & 130.12 & 501345.9 & 4150489 & 0.405696 \\
\hline
\end{tabular}


Table 1 Contd.

\begin{tabular}{|c|c|c|c|c|c|}
\hline YEAR & $\begin{array}{l}\text { MSG } \\
(\%)\end{array}$ & $\begin{array}{l}\text { NFO } \\
\text { (N'M) }\end{array}$ & OPN & $\begin{array}{l}\text { IMP } \\
\text { (\#'M) }\end{array}$ & $\begin{array}{l}\text { EXP } \\
\left(\AA^{\prime} M\right)\end{array}$ \\
\hline 1970 & N/A & -269.9 & 0.389215 & 756.4 & 885.7 \\
\hline 1971 & 6.501738 & 171.6 & 0.503086 & 1078.9 & 1293.4 \\
\hline 1972 & 16.61547 & -58.5 & 0.495483 & 990.1 & 1434.2 \\
\hline 1973 & 25.31896 & 166.1 & 0.659699 & 1224.8 & 2278.4 \\
\hline 1974 & 54.50246 & 1796.8 & 0.473162 & 1737.8 & 5794.8 \\
\hline 1975 & 80.30013 & -427.9 & 0.318232 & 3721.5 & 4925.5 \\
\hline 1976 & 39.23182 & -1090.8 & 0.408269 & 5148.5 & 6751.1 \\
\hline 1977 & 33.76234 & -781.4 & 0.46714 & 7093.7 & 7630.7 \\
\hline 1978 & 1.096369 & -629 & 0.4887 & 8211.7 & 6064.4 \\
\hline 1979 & 20.770 & 3505.7 & 0.61137 & 7472.5 & 10836.8 \\
\hline 1980 & 28.29163 & 265 & 0.738024 & 9095.6 & 14186.7 \\
\hline 1981 & 47.39473 & 1876.8 & 0.116278 & 12839.6 & 11023.3 \\
\hline 1982 & 7.031126 & -489.5 & 0.095034 & 10770.5 & 8206.4 \\
\hline 1983 & 11.95357 & 872.2 & 0.088396 & 8903.7 & 7502.5 \\
\hline 1984 & 15.39495 & 1325.7 & 0.088614 & 7178.3 & 9088 \\
\hline 1985 & 11.93011 & 2009.3 & 0.093433 & 7062.6 & 11720.8 \\
\hline 1986 & 12.44159 & -3843.1 & 0.072362 & 5983.6 & 8920.8 \\
\hline 1987 & 4.232502 & 3361.9 & 0.235453 & 17861.7 & 30360.6 \\
\hline 1988 & 22.91948 & -152.8 & 0.239401 & 21445.7 & 31192.8 \\
\hline 1989 & 34.98785 & 12842.1 & 0.375244 & 30860.2 & 57971.2 \\
\hline 1990 & 3.538415 & 37836.2 & 0.581588 & 45717.9 & 109886.1 \\
\hline 1991 & 45.91967 & 34407.2 & 0.795178 & 89488.2 & 121535.4 \\
\hline 1992 & 27.43463 & 97655.8 & 1.285215 & 143151.2 & 205611.7 \\
\hline 1993 & 47.52662 & 1540.5 & 1.399244 & 165788.8 & 218770.1 \\
\hline 1994 & 53.75794 & 41017.4 & 1.339071 & 162788.8 & 206059.2 \\
\hline 1995 & 34.49515 & 211219.2 & 6.061636 & 755127.7 & 950661.4 \\
\hline 1996 & 19.41172 & 186379.4 & 6.373444 & 562626.6 & 1309543 \\
\hline 1997 & 16.17814 & 154395.9 & 6.911337 & 845716.6 & 1241663 \\
\hline 1998 & 16.039 & -23504.6 & 5.112017 & 837418.7 & 751856.7 \\
\hline 1999 & 22.31778 & 1497.9 & 6.571409 & 862515.7 & 1188970 \\
\hline 2000 & 33.12089 & 1205100 & 8.903206 & 985022.4 & 1945723 \\
\hline 2001 & 48.06769 & 1213574 & 9.036935 & 1358180 & 1867954 \\
\hline 2002 & 27.00465 & 713681.7 & 7.518113 & 1512695 & 1744178 \\
\hline 2003 & 21.55423 & 1349130 & 10.82254 & 2080235 & 3087886 \\
\hline 2004 & 24.11369 & 2494300 & 12.49076 & 1987045 & 4602782 \\
\hline 2005 & 14.02364 & 3725400 & 17.8801 & 2800856 & 7246535 \\
\hline 2006 & 24.35329 & 4027099 & 18.02025 & 3412177 & 7324681 \\
\hline 2007 & 43.09492 & 3264703 & 19.71156 & 4381930 & 8120148 \\
\hline 2008 & 44.23953 & 4625770 & 23.2571 & 5921450 & 9774511 \\
\hline
\end{tabular}

$I N V=$ Gross Private Investment, GDP = Real Gross Domestic Product, TR= Total Tax Revenue, EXCH $=$ Current Exchange rate, INF= Inflation Rate, ED= External Debt, BOP= Balance of Payments, $A T R=$ Average Tax Rate, $M S G=$ Money Supply Growth Rate, NFO= Net Foreign Operation, OPN=Openness of the Economy, IMP = Imports, EXP= Exports, UN= Unemployment Rate, CEXP= Household Consumption Expenditure. 
Sources:

(1) National Bureau of Statistics, General household Survey Report 1995 - 2005

(2) Federal Office of Statistics, annual Abstract of Statistics (various issues)

(3) CBN Statistical Bulletin (various issues)

(4) CBN Annual Reports and Statement of Accounts (various issues)

(5) World Development Report (2007)

Table 2: Unit Root Test: Augmented Dickey-Fuller Test Result

\begin{tabular}{|c|c|c|c|c|c|}
\hline \multirow[b]{2}{*}{ Variable } & \multicolumn{2}{|c|}{ ADF Test Statistic } & \multicolumn{2}{|c|}{$5 \%$ Critical Variables } & \multirow[b]{2}{*}{ Decision } \\
\hline & Level & $1^{\text {st }}$ Difference & Level & $1^{\text {st }}$ Difference & \\
\hline ATR & -3.678830 & - & -2.954021 & - & $1(0)$ \\
\hline $\mathrm{EXCH}$ & 0.382891 & -2.941145 & -2.943427 & -5.298530 & $1(1)$ \\
\hline MSG & 4.756677 & - & -2.954021 & - & $1(0)$ \\
\hline $\mathrm{OPN}$ & 3.473765 & - & -2.960411 & - & $1(0)$ \\
\hline BOP & -1.388723 & -2.941145 & -2.943427 & -5.421698 & $1(1)$ \\
\hline GDP & 1.388723 & -2.941145 & -2.943427 & -5.421698 & $1(1)$ \\
\hline NFO & 5.731559 & - & -2.967767 & - & $1(0)$ \\
\hline ED & 2.060181 & 2.960411 & -2.957110 & -5.411900 & $1(1)$ \\
\hline
\end{tabular}

Source: Researcher's computation

Table 3a : Cointegration Test Results

Unrestricted Cointegration Rank Test (Trace)

\begin{tabular}{|c|c|c|c|c|}
\hline \multirow{2}{*}{$\begin{array}{l}\text { Hypothesized } \\
\text { No. of CE(s) }\end{array}$} & \multirow[b]{2}{*}{ Eigenvalue } & \multirow{2}{*}{$\begin{array}{l}\text { Trace } \\
\text { Statistic }\end{array}$} & \multicolumn{2}{|l|}{0.05} \\
\hline & & & Critical Value & Prob.** \\
\hline None * & 0.984871 & 294.7885 & 125.6154 & 0.0000 \\
\hline At most $1 *$ & 0.841980 & 143.9070 & 95.75366 & 0.0000 \\
\hline At most $2 *$ & 0.600834 & 77.48579 & 69.81889 & 0.0107 \\
\hline At most 3 & 0.454443 & 44.42417 & 47.85613 & 0.1014 \\
\hline At most 4 & 0.290612 & 22.61005 & 29.79707 & 0.2658 \\
\hline At most 5 & 0.227761 & 10.24938 & 15.49471 & 0.2620 \\
\hline At most 6 & 0.025902 & 0.944777 & 3.841466 & 0.3311 \\
\hline
\end{tabular}

Trace test indicates 3 cointegrating eqn(s) at the 0.05 level

* denotes rejection of the hypothesis at the 0.05 level

**MacKinnon-Haug-Michelis (1999) p-values

Table 3b : Cointegration Test Results

Unrestricted Cointegration Rank Test (Maximum Eigenvalue)

\begin{tabular}{|c|c|c|c|c|}
\hline Hypothesized & & Max-Eigen & 0.05 & \\
\hline No. of CE(s) & Eigenvalue & Statistic & Critical Value & Prob. $* *$ \\
\hline None $*$ & 0.984871 & 150.8816 & 46.23142 & 0.0000 \\
\hline At most $1 *$ & 0.841980 & 66.42119 & 40.07757 & 0.0000 \\
\hline At most 2 & 0.600834 & 33.06162 & 33.87687 & 0.0623 \\
\hline At most 3 & 0.454443 & 21.81411 & 27.58434 & 0.2301 \\
\hline At most 4 & 0.290612 & 12.36067 & 21.13162 & 0.5125 \\
\hline At most 5 & 0.227761 & 9.304601 & 14.26460 & 0.2617 \\
\hline At most 6 & 0.025902 & 0.944777 & 3.841466 & 0.3311 \\
\hline
\end{tabular}

Max-eigenvalue test indicates 2 cointegrating eqn(s) at the 0.05 level

* denotes rejection of the hypothesis at the 0.05 level

**MacKinnon-Haug-Michelis (1999) p-values

Source: Researcher's computation 
Table 4: Tax Policy and Balance of Payments

\begin{tabular}{|c|c|c|c|c|}
\hline Variable & Coefficient & Std. Error & t-Statistic & Prob. \\
\hline GDP & 0.217808 & 0.381151 & 0.571447 & 0.5720 \\
\hline NFO & 0.718568 & 0.131481 & 5.465166 & 0.0000 \\
\hline OPN & 9420.466 & 21855.75 & 0.431029 & 0.6695 \\
\hline ED & -0.252603 & 0.073683 & -3.428255 & 0.0018 \\
\hline $\mathrm{EXCH}$ & 3504.167 & 3666.976 & 0.955601 & 0.3469 \\
\hline MSG & -2298.146 & 1842.058 & -1.247597 & 0.2218 \\
\hline ATR & 53029.32 & 49998.09 & 1.060627 & 0.2973 \\
\hline $\mathrm{C}$ & 41545.35 & 85318.93 & 0.486942 & 0.6298 \\
\hline R-squared & 0.977924 & \multicolumn{2}{|c|}{ Mean dependent var } & 474745.6 \\
\hline Adjusted R-squared & 0.972773 & \multicolumn{2}{|c|}{ S.D. dependent var } & 1154510 . \\
\hline S.E. of regression & 190499.9 & \multicolumn{2}{|c|}{ Akaike info criterion } & 27.33735 \\
\hline Sum squared resid & $1.09 \mathrm{E}+12$ & \multicolumn{2}{|c|}{ Schwarz criterion } & 27.68211 \\
\hline Log likelihood & -511.4097 & \multicolumn{2}{|c|}{ F-statistic } & 189.8520 \\
\hline Durbin-Watson stat & 1.904043 & \multicolumn{2}{|c|}{$\operatorname{Prob}(F$-statistic) } & 0.000000 \\
\hline
\end{tabular}

Source: Researcher's computation

Table 5: Regression Results of the First Difference Form

\begin{tabular}{|c|c|c|c|c|c|}
\hline Variable & Coefficient & & Std. Error & t-Statistic & Prob. \\
\hline $\mathrm{C}$ & -27188.25 & & 54140.66 & -0.502178 & 0.6193 \\
\hline D(GDP) & 0.440886 & & 1.435120 & 0.307212 & 0.7609 \\
\hline $\mathrm{D}(\mathrm{NFO})$ & 0.772709 & & 0.206053 & 3.750039 & 0.0008 \\
\hline $\mathrm{D}(\mathrm{OPN})$ & 30745.30 & & 45971.34 & 0.668793 & 0.5089 \\
\hline $\mathrm{D}(\mathrm{ED})$ & -0.262482 & & 0.085038 & -3.086645 & 0.0044 \\
\hline $\mathrm{D}(\mathrm{EXCH})$ & 6213.289 & & 3838.483 & 1.618684 & 0.1163 \\
\hline D(MSG) & -2228.442 & & 2283.513 & -0.975883 & 0.3372 \\
\hline D(ATR) & -5514.823 & & 83301.20 & -0.066203 & 0.9477 \\
\hline R-squared & & 0.820974 & & Mean dependent var & 112181.6 \\
\hline Adjusted R-squared & & 0.777760 & & S.D. dependent var & 545489.8 \\
\hline S.E. of regression & & 257156.4 & & Akaike info criterion & 27.94157 \\
\hline Sum squared resid & & $1.92 \mathrm{E}+12$ & & Schwarz criterion & 28.28987 \\
\hline Log likelihood & & -508.9190 & & F-statistic & 18.99819 \\
\hline Durbin-Watson stat & & 2.340366 & & Prob(F-statistic) & 0.000000 \\
\hline
\end{tabular}

Source: Researcher's computation 